\title{
REKONSTRUKSI DENGAN METODE PERHITUNGAN-BALIK PADA SIDANG JESSICA KUMALA WONGSO
}

\author{
Paul Salim ${ }^{1}$ \\ ${ }^{1}$ Global Dynamics Inc., Technology \& Innovation Center \\ $105,3750-46^{\text {th }}$ Ave SE, Calgary, Alberta, T2B 0L1, Canada \\ Email : pws_60628@hotmail.com
}

\begin{abstract}
ABSTRAK
Saat persidangan Jessica Kumala Wongso pada tahun 2016, jaksa penuntut umum mengajukan dua ahli kimia yang memakai perhitungan-balik untuk rekonstruksi waktu racun natrium sianida dimasukkan kedalam es kopi Vietnam. Dua ahli kimia tersebut adalah Dr. Nursamran Subandi, MSi dan Dr.Rer.nat. I Made Agus Gelgel Wirasuta, MSi, Apt. Untuk perhitungan-balik, mereka mengajukan rumus-rumus yang menghubungkan waktu dan konsentrasi ion sianida, menghitung waktu untuk mencapai konsentrasi ion sianida $7900 \mathrm{mg} / \mathrm{L}$ yang diukur dari barang bukti kopi, dan mengurangkan waktu terhitung dari 10 Januari 2016, 10:30 (saat 7900 $\mathrm{mg} / \mathrm{L}$ diukur) untuk menentukan kapan racun sianida dimasukkan kedalam barang bukti. Rumus dari ahli pertama menghasilkan konsentrasi ion sianida dengan SSE (the sum of squares of error) 12036 yang menunjukkan rumus tidak akurat. Ahli ini mengajukan hasil rekonstruksi yang salah ke pengadilan, yaitu 6 Januari 2016, 16:39:36, bukannya hasil yang benar 6 Januari 2016, 16:20:24. Ahli kedua mengajukan dua rumus yang menghasilkan konsentrasi ion sianida dengan SSE 16010 dan 24448 yang menunjukkan rumus tidak akurat. Rekonstruksi yang dihasilkan oleh ahli ini benar, yaitu 6 Januari 2016, 16:28:12 and 16:45:00. Sebagai penganti dari rumus-rumus yang tidak akurat yang ditandai dengan nilai SSE yang tinggi, diajukanlah rumus baru yang lebih akurat dalam menghasilkan konsentrasi ion sianida dengan SSE 50. Dengan rumus ini, rekonstruksi yang dihasilkan adalah 6 Januari 2016, 13:13:12, yang menunjukkan bahwa Jessica Kumala Wongso tidak bersalah, karena dia punya alibi yang kuat pada saat racun sianida dimasukkan kedalam kopi.

Kata kunci: rekonstruksi, keracunan natrium sianida, es kopi Vietnam, jessica wongso
\end{abstract}

\begin{abstract}
When Jessica Kumala Wongso was on trial in 2016, the prosecution brought in two chemical expert witnesses that used retrograde calculation to reconstruct time Vietnamese iced coffee was spiked with sodium cyanide poison. Both witnesses were Dr. Nursamran Subandi, MSi and Dr.Rer.nat. I Made Agus Gelgel Wirasuta, MSi, Apt. On retrograde calculation, they put forward formulae relating time and cyanide ion concentration, calculated time to reach cyanide ion concentration $7900 \mathrm{mg} / \mathrm{L}$ measured from the crime scene evidence of coffee, and subtracted the time from $10^{\text {th }}$ January 2016, 10:30 (when the $7900 \mathrm{mg} / \mathrm{L}$ was measured) to determine when the evidence was spiked with cyanide poison. A formula from the first witness generated cyanide ion concentration with SSE (the sum of squares of error) 12036 indicating an inaccurate formula. The witness submitted an erroneous reconstruction result to the court, i.e. $6^{\text {th }}$ January 2016, 16:39:36, not the correct one $6^{\text {th }}$ January 2016, 16:20:24. The second witness put forward two formulae that generated cyanide ion concentration with SSE 16010 and 24448 indicating inaccurate formulae. The reconstruction results generated by the witness were correct, i.e. $6^{\text {th }}$ January $2016,16: 28: 12$ and 16:45:00. To replace the aforementioned inaccurate formulae with high SSEs, a new formula is put forward and much more accurate in generating cyanide ion concentration with SSE 50. With the formula, a reconstruction result generated is $6^{\text {th }}$ January 2016, 13:13:12, showing that Jessica Kumala Wongso is innocent, because she had strong alibi for the time the coffee was spiked with cyanide poison.
\end{abstract}

Keywords: reconstruction, sodium cyanide poisoning, Vietnamese iced coffee, jessica wongso 


\section{PENDAHULUAN}

Kematian dari Wayan Mirna Salihin (WMS) setelah meminum Vietnamese iced coffee (VIC) yang mengandung racun natrium sianida $(\mathrm{NaCN})$ di Olivier Cafe, Grand Indonesia, Jakarta pada 6 Januari 2016 telah menyebabkan Jessica Kumala Wongso (JKW) dipenjara selama 20 tahun [1]. Dua ahli kimia yang diajukan oleh jaksa penuntut umum menggunakan metode perhitungan-balik dan mengatakan bahwa NaCN dimasukkan ke VIC pada 6 Januari 2016 antara 16:30 dan 16:45 [2],[3]. Dua ahli tersebut adalah Dr. Nursamran Subandi, MSi dan Dr.Rer.nat. I Made Agus Gelgel Wirasuta, MSi, Apt, yang selanjutnya masing-masing akan disebut sebagai Ahli I dan Ahli II di manuskrip ini.

Perhitungan-balik dilakukan atas dasar konsentrasi ion sianida $\mathrm{CN}^{-}=7900 \mathrm{mg} / \mathrm{L}$ dalam sisa VIC yang diminum WMS dan yang diukur oleh pusat laboratorium forensik (Puslabfor) pada 10 Januari 2016, 10:30 [4],[5] dan pengujian yang juga dilakukan oleh Puslabfor atas penurunan konsentrasi ion $\mathrm{CN}^{-}$ dalam VIC versus waktu yang disajikan pada tabel 1 pada kolom ke 1 dan 2 dari kiri [6].

Ahli I menghasilkan model matematik yang diperoleh dari curve fitting antara konsentrasi ion $\mathrm{CN}^{-}$dari hasil pengujian Puslabfor dan waktu dan menghasilkan rumus (1) $[2]$.

$C N=0.1569 t^{2}-35.601 t+$

9834.4

dimana:

$C N=$ konsentrasi ion $\mathrm{CN}^{-}$dalam VIC, $\mathrm{mg} / \mathrm{L}$ $t=$ waktu, jam

Dibandingkan dengan konsentrasi ion $\mathrm{CN}^{-}$dari Puslabfor, konsentrasi ion $\mathrm{CN}^{-}$dari rumus (1) mempunyai SSE (the sum of squares of error) 12036 yang ditunjukkan pada tabel 1. Ahli II menggunakan model matematik laju penguraian dan menghasilkan rumus (2) dan (3) [6].

$$
\begin{aligned}
& C N=2350.3 e^{-0.02119 t}+ \\
& 7551.568 e^{-5.67 \mathrm{E}-7 t} \\
& C N=2350.3 e^{-0.0229 t}+ \\
& 7599.409 e^{-5.67 \mathrm{E}-7 t}
\end{aligned}
$$

Dibandingkan dengan konsentrasi ion $\mathrm{CN}^{-}$dari Puslabfor, konsentrasi ion $\mathrm{CN}^{-}$dari rumus (2) mempunyai SSE 16010, sedangkan yang dari rumus (3) mempunyai SSE 24448 yang ditunjukkan pada tabel 1 .

Rumus-rumus yang dihasilkan oleh Ahli I dan Ahli II tidak akurat dalam menghitung konsentrasi ion $\mathrm{CN}^{-}$dengan ditandai oleh nilai SSE yang tinggi. Oleh sebab itu, perlu dicari rumus baru yang lebih akurat.

\section{METODE PENELITIAN}

Hasil pengujian Puslabfor [6] yang menghubungkan konsentrasi ion $\mathrm{CN}^{-}$dan waktu dipakai sebagai pembanding untuk menentukan model matematik terbaik dengan melihat nilai SSE yang dicapai. Dari berbagai model matematik yang diuji, model terbaik mempunyai SSE terkecil.

\section{HASIL dan PEMBAHASAN}

Model matematik terbaik yang dihasilkan tampak pada rumus dibawah ini:

Jika $t \leq 71.5855$, 
$C N=\frac{7468.64}{1-0.243999 e^{-0.0151098 t}}$ tetapi jika tidak,

$C N=\frac{7745.42}{1-0.989391 e^{-0.0420583 t}}$

Dibandingkan dengan konsentrasi ion $\mathrm{CN}^{-}$dari Puslabfor, konsentrasi ion $\mathrm{CN}^{-}$dari rumus $(4 \mathrm{a}, \mathrm{b})$ mempunyai SSE 50 yang menunjukkan hasil perhitungan sangat akurat.

Pada metode perhitungan-balik, rumus-rumus (1) sampai dengan (4a,b) dipakai untuk rekonstruksi kapan racun sianida dimasukkan ke VIC berdasarkan $C N=7900 \mathrm{mg} / \mathrm{L}$ yang diukur 10 Januari 2016, 10:30. Untuk setiap rumus, hitunglah waktu (sebutlah $t_{1}$ ) ketika $C N=7900$ mg/L dengan memakai Goal Seek software di OpenOffice spreadsheet dan kemudian kurangkan $t_{1}$ dari 10 Januari 2016, 10:30 dengan memakai public software [7],[8].

Tabel 1. Perbandingan $C N$ Pada Berbagai Waktu.

\begin{tabular}{|c|c|c|c|c|c|}
\hline \multirow[t]{2}{*}{$t$, jam } & \multicolumn{5}{|c|}{$C N, \mathrm{mg} / \mathrm{L}$} \\
\hline & Pengujian & Rumus (1) & Rumus (2) & Rumus (3) & Rumus $(4 a, b)$ \\
\hline 0 & 9880 & 9834 & 9902 & 9950 & 9879 \\
\hline 24 & 8992 & 9070 & 8965 & 8956 & 8996 \\
\hline 48 & 8475 & 8487 & 8401 & 8382 & 8469 \\
\hline 72 & 8135 & 8084 & 8062 & 8051 & 8135 \\
\hline 96 & 7883 & 7862 & 7859 & 7860 & 7883 \\
\hline 120 & 7795 & 7821 & 7736 & 7749 & 7795 \\
\hline The Sun & $\begin{array}{l}\text { uares of Error } \\
\mathrm{mg} / \mathrm{L})^{2}\end{array}$ & 12036 & 16010 & 24448 & 50 \\
\hline
\end{tabular}

Tabel 2. Hasil Rekonstruksi Dengan Metode Perhitungan-Balik.

\begin{tabular}{|c|c|c|}
\hline Sumber & $t_{1}$, jam & $\begin{array}{l}\text { Saat sianida masuk } \\
\text { kedalam VIC }\end{array}$ \\
\hline $\begin{array}{l}\text { Rumus (1) } \\
\text { dari Ahli I }\end{array}$ & 90.16 & $6 / 1 / 2016,16: 20: 24$ \\
\hline $\begin{array}{l}\text { Rumus (2) } \\
\text { dari Ahli II }\end{array}$ & 90.03 & $6 / 1 / 2016,16: 28: 12$ \\
\hline $\begin{array}{l}\text { Rumus (3) } \\
\text { dari Ahli II }\end{array}$ & 89.75 & $6 / 1 / 2016,16$ \\
\hline $\begin{array}{l}\text { Rumus } \\
(4 \mathrm{a}, \mathrm{b})\end{array}$ & 93.28 & $6 / 1 / 2016,13: 13: 12$ \\
\hline $\begin{array}{l}\text { Tabel } 2 \\
\text { perhitungan- } \\
\text { Hasil }\end{array}$ & $\begin{array}{l}\text { menı } \\
\text {-balik. } \\
\text { perhitur }\end{array}$ & $\begin{array}{l}\text { unjukkan hasil } \\
\text { gan-balik pada }\end{array}$ \\
\hline
\end{tabular}

tabel 2 menunjukkan:

1. Hasil rekonstruksi dari Ahli I dengan memakai rumus (1) yaitu 6 Januari 2016, 16:39:36 [2] adalah salah. Ketika mengurangkan 90.16 jam dari 10 Januari 2016, 10:30, Ahli I seharusnya menghasilkan 6 Januari 2016, 16:20:24. Dengan demikian, hasil rekonstruksi dari Ahli I yang diajukan ke persidangan adalah salah.

2. Hasil rekonstruksi dari Ahli II yang menggunakan rumus (2) dan yang mengatakan bahwa racun sianida dimasukkan ke VIC pada 6 Januari 2016, 16:30 
[6] bisa direproduksi di tabel 2 dengan perbedaan waktu kurang dari dua menit, yaitu 6 Januari 2016, 16:28:12. Ini berarti bahwa hasil rekonstruksi dari Ahli II yang diajukan ke persidangan adalah benar.

3. Hasil rekonstruksi dari Ahli II dengan rumus (3) yaitu 6 Januari 2016, 16:45 [6] bisa direproduksi secara total di tabel 2, sehingga hasil rekonstruksi kedua dari Ahli II yang diajukan ke persidangan adalah benar.

4. Rumus-rumus yang dipakai sampai saat ini tidak akurat dalam menghasilkan konsentrasi ion sianida yang mempunyai kesalahan tinggi (atau, SSE diatas 10000), sehingga perlu diragukan hasil rekonstruksi waktu penambahan racun sianida ke VIC yang diperoleh dari rumus-rumus ini.

5. Rumus (4a,b) menghasilkan konsentrasi ion sianida yang sangat akurat dengan SSE 50. Dengan rumus ini, diperlukan waktu 93.28 jam untuk mencapai $C N=7900 \mathrm{mg} / \mathrm{L}$. Mengurangkan 93.28 jam dari 10 Januari 2016, 10:30, memberi jawaban 6 Januari 2016, 13:13:12 sebagai waktu penambahan racun sianida ke VIC. Jadi, disimpulkan bahwa JKW tidak bersalah, karena dia punya alibi yang kuat saat penambahan racun sianida kedalam VIC terjadi pada 6 Januari 2016, 13:13:12.

\section{KESIMPULAN}

Berdasarkan model matematik paling akurat untuk pengujian dari Puslabfor atas penurunan konsentrasi ion sianida dalam VIC, hasil rekonstruksi waktu penambahan racun sianida kedalam VIC adalah 6 Januari 2016, 13:13:12.

\section{DAFTAR PUSTAKA}

[1] Pengadilan Negeri Jakarta Pusat. Putusan Nomor 777/Pid.B/2016/PN.JKT.PST.

2016 Oct [cited 2019 Jun 12]. Available from: http://www.academia.edu/370506 79/Putusan_JESSICA_KUMAL A_alias JESSICA_KUMALA WONGSO_alias_JESS_7772016_1

[2] Ibid., 99 - 100.

[3] Ibid., 179.

[4] Ibid., 328.

[5] Ibid., 98.

[6] KOMPASTV. Ahli Toksikologi Forensik Jadi Saksi - Sidang Kasus Kopi Bersianida. 2016. Available from: http://www.youtube.com/watch?v $=8 \mathrm{fKPHcKdPOc} \& \mathrm{t}=8740 \mathrm{~s}$, waktu 2:25:33 - 2:29:25.

[7] CalculatorSoup. Decimal To Time Calculator. 2020. Available from:

http://www.calculatorsoup.com/c alculators/time/decimal-to-timecalculator.php

[8] Calculator.net. Time Calculator. 2020. Available from: http://www.calculator.net/timecalculator.html

[9] Budiawan. Peran Toksikologi Forensik Dalam Mengungkap Kasus Keracunan Dan Pencemaran Lingkungan. Indonesian J Legal Forensic Sci 2008;1(1):35-39. 